\title{
REPRODUCTION OF SPECIES OF THE GENUS Cichla IN A RESERVOIR IN SOUTHEASTERN BRAZIL
}

\author{
GOMIERO, L. M. and BRAGA, F. M. S. \\ Departamento de Zoologia, Instituto de Biociências, Universidade Estadual Paulista (UNESP), Av. 24-A, n. 1515, \\ C.P. 199, CEP 13506-900, Rio Claro, São Paulo, Brazil \\ Correspondence to: Leandro Muller Gomiero, Departamento de Zoologia, Instituto de Biociências, \\ Universidade Estadual Paulista (UNESP), Av. 24-A, n. 1515, C.P. 199, CEP 13506-900, \\ Rio Claro, São Paulo, Brazil, e-mail: leanmg@rc.unesp.br \\ Received January 29, 2003 - Accepted August 22, 2003 - Distributed August 31, 2004
}

(With 7 figures)

\begin{abstract}
The reproduction of two species of Cichla (Cichla cf. ocellaris and C. monoculus, commonly known in Brazil as tucunaré) introduced in the Volta Grande Reservoir, southeastern Brazil, was analyzed. The period for spawning began at the end of the dry season (September) and extended until the end of the rainy season (January). The length of the first gonad maturation $\left(L_{50}\right)$ and the length at which all fish are considered adults $\left(L_{100}\right)$ were very similar for both species and coincide with the length of fish at one year of age. The analysis of disassociated oocytes evidenced a partitioned spawning, and that $C$. monoculus was more prolific than $C$. cf. ocellaris. The low fecundity, partitioned spawning, bi-parental brood care, and supplying of food for the young are related to the way of life, habitat, and reproductive behavior of these fish.
\end{abstract}

Key words: Cichla, reproduction, fecundity, reservoir, Brazil.

\section{RESUMO}

\section{Reprodução de espécies de Cichla em um reservatório do Sudeste do Brasil}

Foi analisada a reprodução das espécies de tucunarés (Cichla cf. ocellaris e Cichla monoculus) introduzidas no reservatório de Volta Grande, Sudeste do Brasil. A época das desovas teve início no final do período de seca (setembro) e estendeu-se até o final do período chuvoso (janeiro). O comprimento da primeira maturação gonadal $\left(L_{50}\right)$ e o comprimento a partir do qual os peixes dessas espécies são considerados adultos $\left(L_{100}\right)$ foram muito próximos e coincidem com os comprimentos de peixes com um ano de vida. A análise dos ovócitos dissociados evidenciou a desova parcelada, sendo C. monoculus mais prolífico do que $C$. cf. ocellaris. A baixa fecundidade, a desova parcelada, o cuidado biparental e o suprimento de alimento para os jovens estão relacionados ao modo de vida, ao habitat e ao comportamento reprodutivo desses peixes.

Palavras-chave: Cichla, reprodução, fecundidade, reservatório, Brasil.

\section{INTRODUCTION}

Increasing electricity demand requires the construction of many hydroelectric plants that, as a result of river damming, have innumerable consequences for fish populations. A unavoidable result with respect to aquatic fauna is the alteration in abundance of animal species, with excessive proliferation of some and reduction, or even elimination, of others. The impact level is mainly related to local fauna characteristics, location of the dam with respect to population distribution in the area, morphometrics of the basin, existence of other dams upstream, dam design, and operational procedures of the plant itself (Agostinho, 1994). 
Introduction of species from other basins into reservoirs is a common practice. Since the $60 \mathrm{~s}$, significant transfer of native species from the Amazon basin into fish-rearing centers in northeastern Brazil has occurred, followed by their subsequent transfer into southeastern and southern Brazil. From these rearing centers, the species can easily reach nearby natural water bodies, which incurs high risk, especially in the case of predatory fish species (Agostinho \& Julio Jr., 1996). When environments are altered, native species are especially vulnerable (Elvira \& Almodóvar, 2001). An example is the the Volta Grande Reservoir where at least 15 years ago two species of piscivorous fish easily distinguished by their external coloration, sagittae, and meristic characters, were introduced (Cichla spp.).

Introduced species affect native species through competition for available resources, predation, pathogen transfer, or simply by habitat alteration. Introduction of alien species and consequent natural habitat loss were the factors responsible for most animal species extinctions during the twentieth century (Elvira \& Almodóvar, 2001). Stable environments are more susceptible to the introduction of new species (specially piscivores) than relatively less stable ones; however, every natural system is unique and identical changes are rarely possible (Zaret, 1982). Exponential population growth is common among introduced predatory species, bringing with it more intraspecific competition for space and food (Bedarf et al., 2001). As a consequence, biomass of the introduced species may decrease (Williams et al., 1998).

The family Cichlidae is the most species-rich of all freshwater percoid fish (1,400 species), displaying great variation in reproductive behaviors (McKaye, 1984; Murray, 2001). Out of the 495 families of bony fish, about $20 \%$ exhibit parental care and only two of them, Pomacentridae and Cichlidae, include genera with transitions between kinds of parental care (Gittleman, 1981). The perciforms of the family Cichlidae generally present local sedentary populations, stable food resources, a prolonged breeding season, and parental care, attributes corresponding to an equilibrium strategy (Winemiller, 1989). Parental care occurs in many different manners, and variation exists as to which sex takes care of the brood; nevertheless, brood care by both parents is the ancestral condition in relation to single-parent brood care (Goodwin et al., 1998). Parental care in animals is determined by the complexity of behavioral interactions between parents and their brood, and the amount of food destined for the brood is clearly related to the type and extent of this care (Godfray, 1995). Male fish with external fecundation generally have a high probability of being genetically related to offspring hatching at the spawning site; this is a precondition to the evolution of parental care (Blumer, 1979). Cichlids possess fins and muscles associated to control of certain movements including fanning water, an important requirement in lentic waters since it supplies eggs with a constant water flux for oxygenation and removal of debris from their surface, as well as minimizing the chance of fungi infection (Zaret, 1980; Blumer, 1986).

Species of the genus Cichla, commonly known astucunaré in Brazil, are basically restricted to transparent waters with high temperatures and access to lentic water habitats for feeding and/or reproduction; in these habitats, they are frequently the dominant diurnal piscivores (Winemiller, 2001). These fish, which lay their eggs on the substrate, in accordance with their reproductive strategy commonly establish a territory where eggs are laid and guarded. A couple remains together throughout the parental care period, which extends from the time of spawning until the immature individuals become totally independent (McKaye, 1977; Zaret, 1980; Winemiller et al., 1997).

In species of Cichla reared in captivity, sexual maturity occurs between 11 and 12 months of age, with the males always being more developed than the females (Fontenele, 1950). Before mating, cichlids develop secondary sexual characteristics: post-orbital nuptial humps in the males and bright body colorations in both sexes (Fontenele, 1948; Winemiller et al., 1997). The objective of the present work was to characterize the reproduction of Cichla $\mathrm{cf}$. ocellaris (Bloch \& Schneider, 1801) and Cichla monoculus (Bloch \& Schneider, 1801), as well as its periodicity and fecundity in the Volta Grande Reservoir.

\section{MATERIAL AND METHODS}

The Volta Grande Reservoir, located in a tropical area $\left(48^{\circ} 25^{\prime}\right.$ and $47^{\circ} 35^{\prime} \mathrm{W}, 19^{\circ} 57^{\prime}$ and $\left.20^{\circ} 10^{\prime} \mathrm{S}\right)$, resulted from the damming of the Rio Grande River. This river is located between the states of Minas Gerais and São Paulo in southeastern Brazil (see Fig. 1). The climate is typically tropical with a mean annual temperature of $22^{\circ} \mathrm{C}$ and a mean 
annual rainfall of $1.635 \mathrm{~mm}$. There are two typical seasonal periods: a warm and rainy season from October to April, and a cool and dry season from May to September. The Volta Grande Reservoir has a flooded area of $221,7 \mathrm{~km}^{2}$ with a water volume of $2.268 \mathrm{~km}^{3}$ destined for electric energy production (Braga \& Gomiero, 1997).

Collections were made during April and June 1997, and every month from September 1997 until August 1998. Two kinds of fishing equipment were used: simple nets with meshes of 2.0, 3.0, 4.0, 5.0, and $6.0 \mathrm{~cm}$ between adjacent knots, and fishing rods with natural or artificial bait. Each specific mesh set was $150 \mathrm{~m}$ long and $1.5 \mathrm{~m}$ in height, totaling $750 \mathrm{~m}$

Data for total weight $(T W)$ in grams, total length $(T L)$ in centimeters, sex, and gonad maturation stage were taken for each individual captured of each species. The maturation stage of each specimen was determined macroscopically, considering coloration, transparency, superficial vascularization and, for ovaries, oocyte visualization and appearance. In agreement with a previously established scale, four different maturation stages were considered: $\mathrm{A}$, immature; $\mathrm{B}$, in maturation;
$\mathrm{C}$, mature; and D, spent. The reproductive period was analyzed according to seasonal variations of the different maturation stage frequencies during collecting periods. The mean length $L_{50}$ is of the first gonad maturation at which $50 \%$ of the individuals are adult, i.e., they have begun the reproductive cycle. The length at which all individuals are apt for reproduction is represented by $L_{100}$. Both $L_{50}$ and $L_{100}$ were estimated following Vazzoler (1996).

For the study of fecundity, in accordance with Vazzoler (1996) ovaries in stage C were extracted from the visceral cavity and weighted; their membranes were then sectioned longitudinally throughout and immersed in modified Gilson solution. The vials containing the oocytes and Gilson solution were periodically shaken and, after total disassociation, the oocytes were washed several times in 70\% alcohol and kept in this solution. Fecundity was estimated according to the volumetric method (Vazzoler, 1996). Individual fecundity was estimated considering $N^{\prime}=$ $S n / s$, where $S$ is the volume of alcohol used to homogenize the mass of oocytes, and $n$ is the total number of oocytes counted in a sample of $s$ volume obtained through a Stempel pipette.

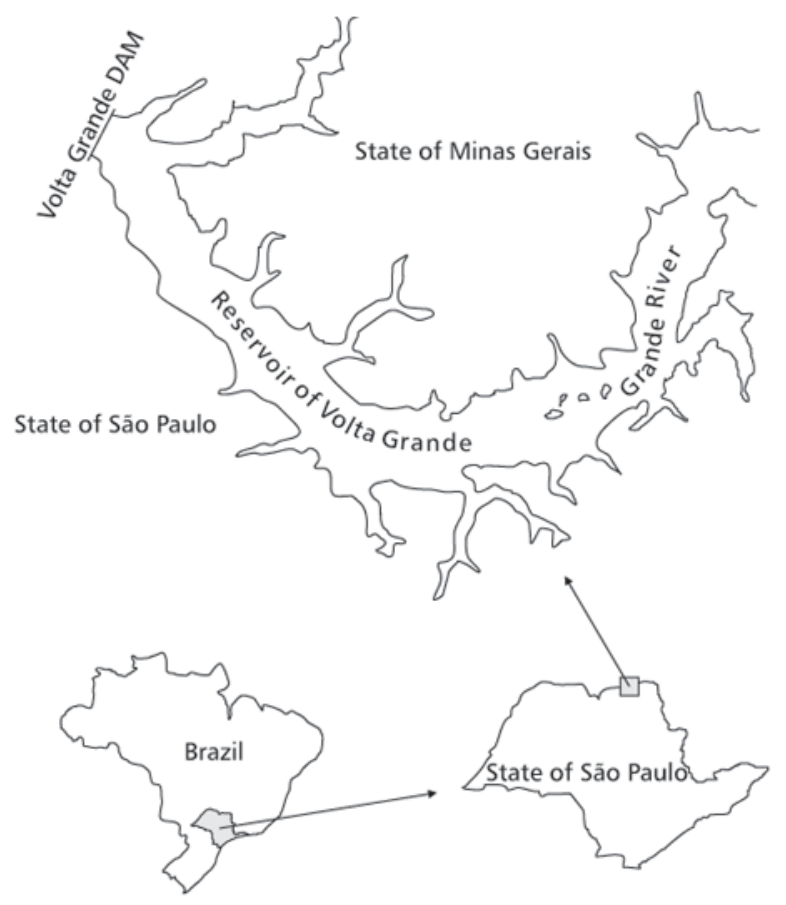

Fig. 1 - Reservoir of Volta Grande $\left(48^{\circ} 25^{\prime}\right.$ and $47^{\circ} 35^{\prime} \mathrm{W}, 19^{\circ} 57^{\prime}$ and $\left.20^{\circ} 10^{\prime} \mathrm{S}\right)$. 
In this way we estimated the total number of oocytes, $N^{\prime}$, contained in the pair of disassociated ovaries. Since individual fecundity represents the number of mature oocytes and not the total number of oocytes contained in the ovaries, the formula $N=$ $N^{\prime} P / 100$ was used to estimate individual fecundity, where $P$ is the percentage in the ovaries of oocytes with the diameter necessary for the oocytes to initiate the maturation process, in relation to the total number of oocytes $\left(N^{\prime}\right)$. Once individual fecundity was established for both species of Cichla, we also estimated the relative fecundity in relation to length $(F R L)$ and to weight $(F R W)$ for both species in comparison with one another.

\section{RESULTS}

During the collecting period, 459 specimens of C. cf. ocellaris and 170 of C. monoculus were sampled.

The distribution of the gonad maturation stages of all exemplars captured for $C$. cf. ocellaris showed a prevalence of B stage (in maturation); however, C stage (mature) appeared in April, September, November, and December 1997 and in all the collections made during 1998. The D stage (spent) occurred in April, May, and July 1998. For C. monoculus there was also a prevalence of $\mathrm{B}$ stage, but the $\mathrm{C}$ stage occurred in all collections, except for the ones made during September 1997 and March 1998. Stage D appeared in November 1997, February 1998, and July 1998 (see Figs. 2 and 3).

Immature individuals of $C$. cf. ocellaris occurred from January to August 1998, while for $C$. monoculus, immatures appeared in December 1997 and from February to June 1998. For both species there was a higher frequency of immature individuals during February (see Figs. 4 and 5).

The $L_{50}$ and $L_{100}$ for $C$. cf. ocellaris were 20 and $29 \mathrm{~cm}$, respectively, and for $C$. monoculus 21.5 and $25 \mathrm{~cm}$, respectively. In the analysis of disassociated oocytes, 19 pairs of ovaries were used for Cichla $\mathrm{cf}$. ocellaris and 38 for C. monoculus, divided in similar maturation groups. The ovaries corresponded to specimens collected during 1997 and 1998.

For $C$. cf. ocellaris, the stock batch was shown to correspond to oocytes in diameter classes of up to 306-367.2 micrometers, while developing or mature oocytes occurred from the 795.6 micrometer class until that of 2,570.4 micrometers (see Fig. 6). In C. monoculus, the stock batch also corresponded to oocyte diameter classes of up to 306-367.2 micrometers and developing or mature oocytes were found in all classes from 673.2 micrometers to 2,815.2 micrometers (see Fig. 7).

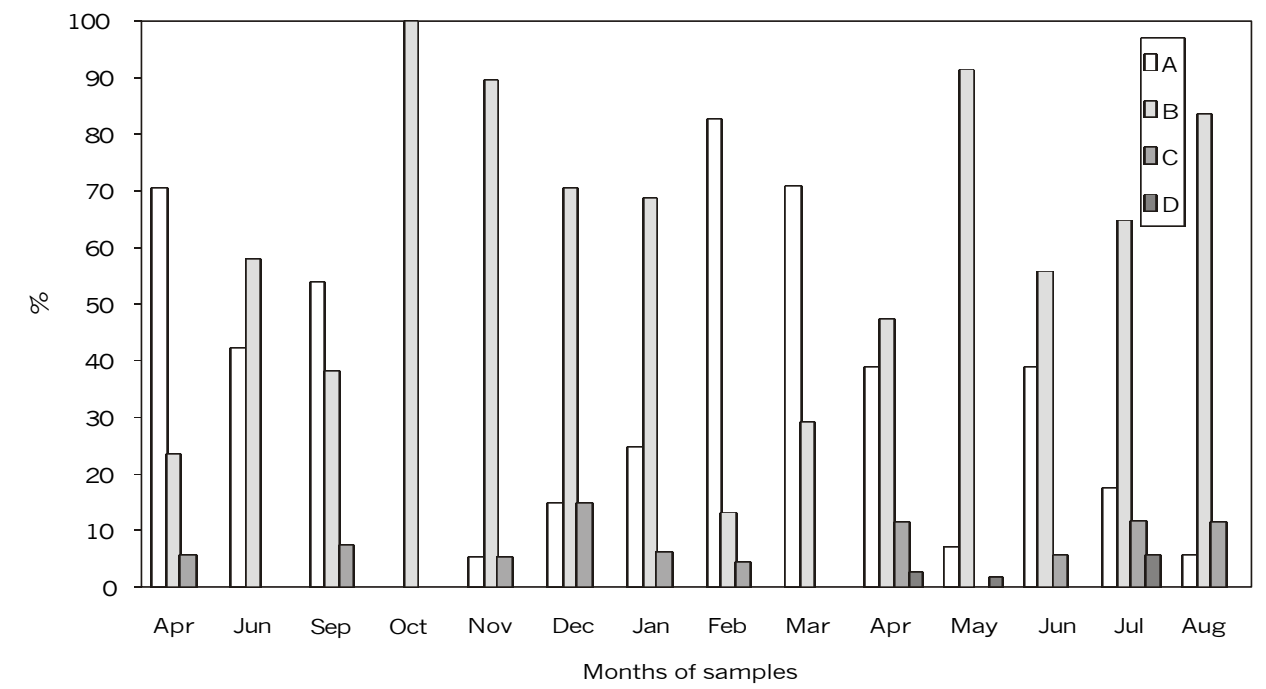

Fig. 2 - Frequency (in percentage) of the mature stages of Cichla cf. ocellaris obtained in the collections made from April 1997 to August 1998. 


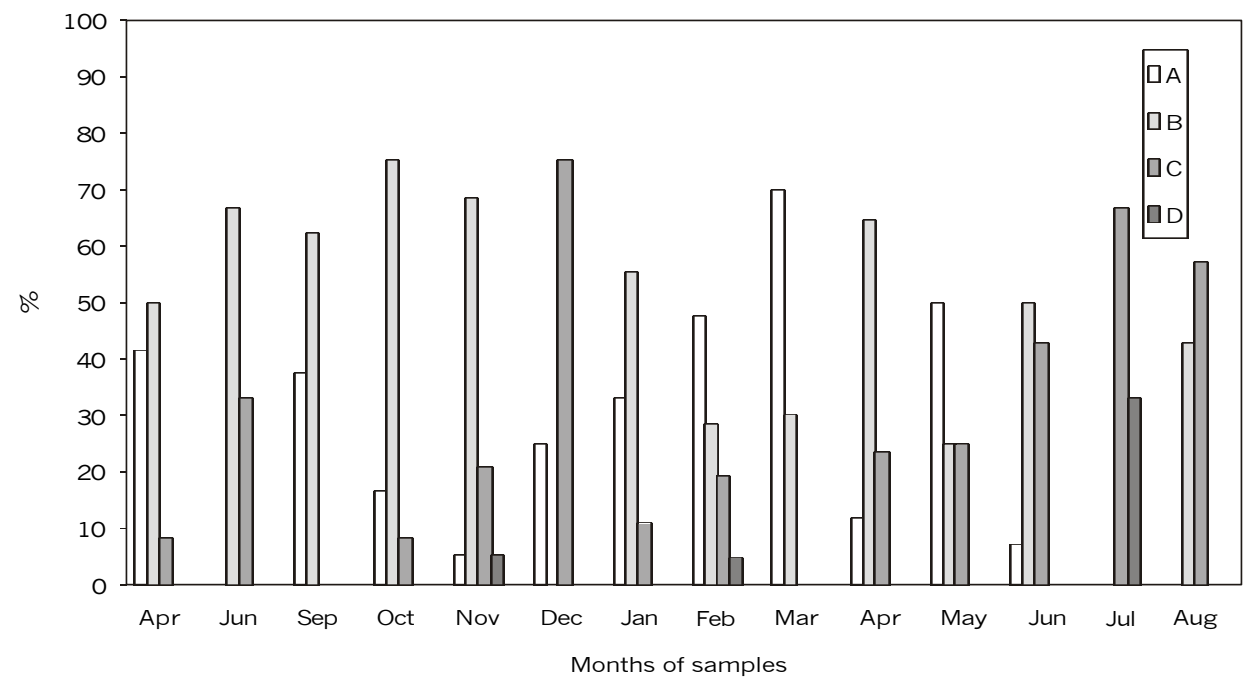

Fig. 3 - Frequency (in percentage) of the mature stages of Cichla monoculus obtained in the collections made from April 1997 to August 1998.

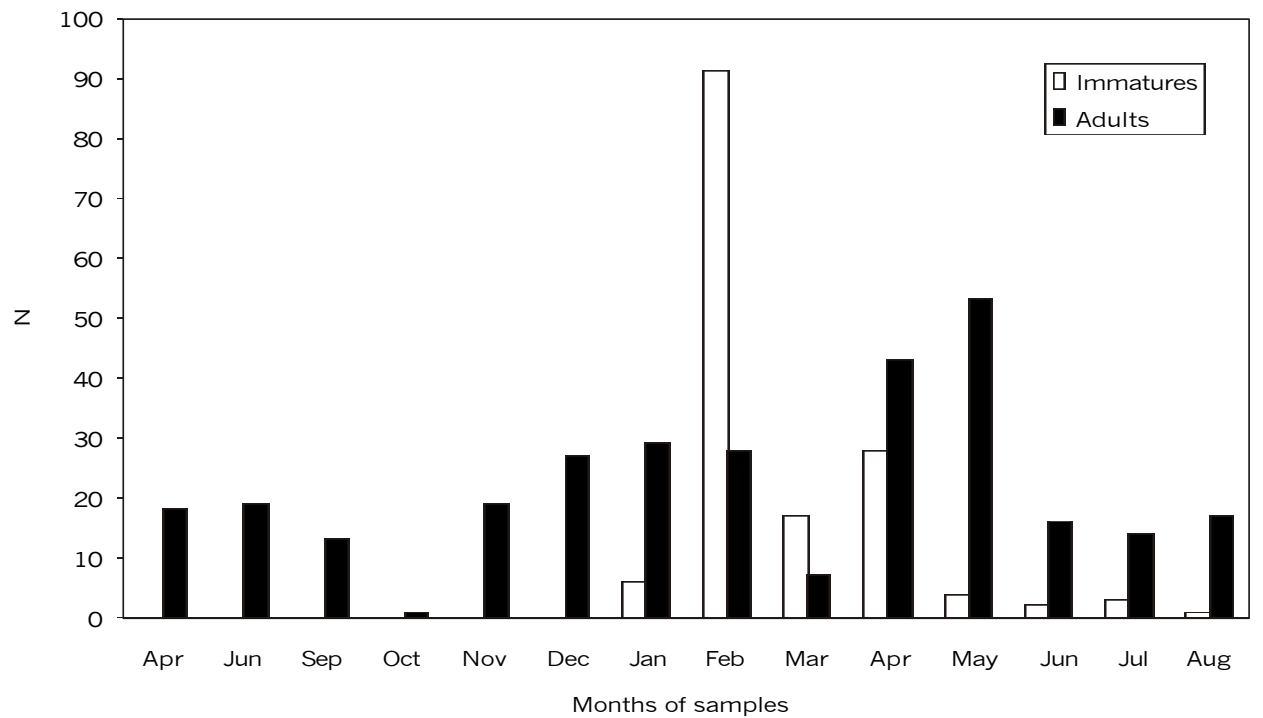

Fig. 4 - Numerical distribution of immature and adult individuals found in each collection of Cichla cf. ocellaris made from April 1997 to August 1998.

The data corresponding to total fish length $(T L)$, total weight $(T W)$, total number of oocytes $(N)$, number of developing and mature oocytes $(N)$, fecundity in relation to length $(F R L)$, and fecundity in relation to weight $(F R W)$, for each pair of ovaries and for both species analyzed are summarized in
Tables 1 and 2. The mean number of mature oocytes for $C$. cf. ocellaris was $13,769.22$ with a standard error of 3,401 .

For C. monoculus this mean was slightly higher, with 17,987.55 oocytes and a standard error of $2,522.8$. 


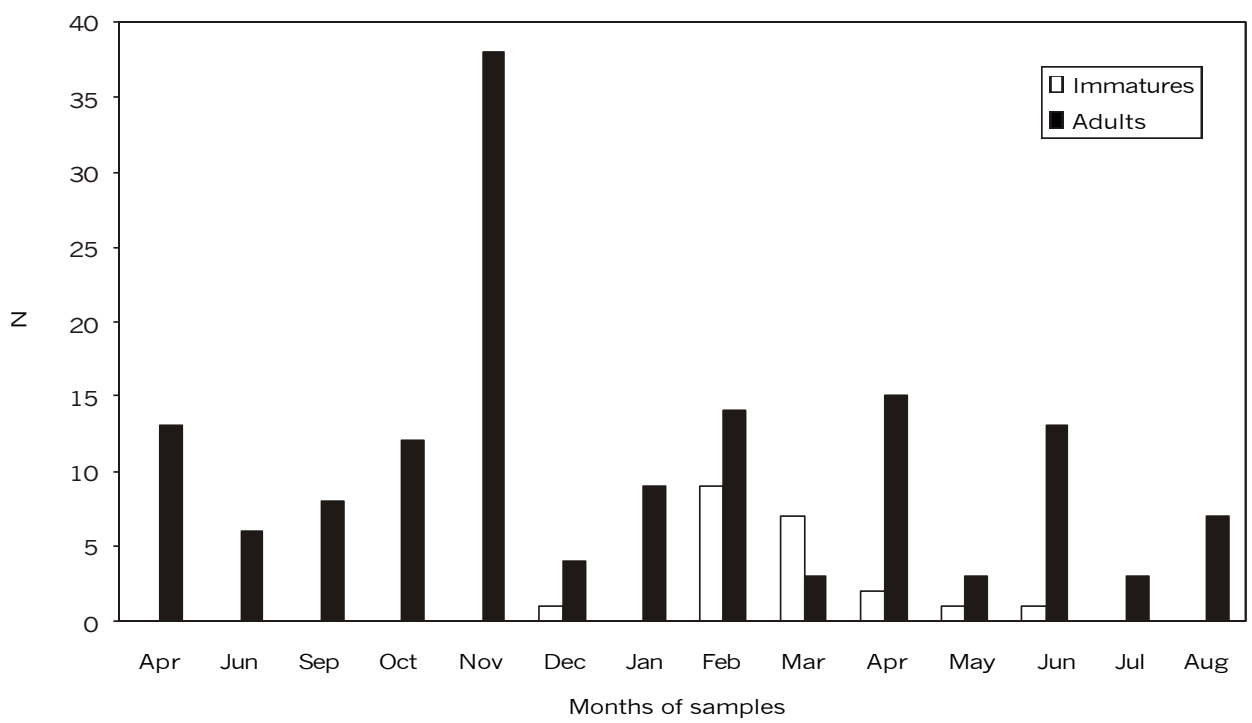

Fig. 5 - Numerical distribution of immature and adult individuals found in each collection of Cichla monoculus made from April 1997 to August 1998.

\section{DISCUSSION}

The maturation stages showed that C-stage individuals (mature) could be found during throughout the seasons, but reproduction occurred mainly from September to January (spring and summer). The highest frequency of immature individuals of both species occurred during summer and autumn, showing that, for these species, eggs were laid during spring and the beginning of summer, seasons that correspond to the higher incidence of rain. In tropical waters where temperatures apparently do not limit egg laying and in relatively non-seasonal environments, the seasons are imposed by environmental factors (such as competition for spawning sites or habitats) that lead to nutrient accumulation and biotic pressures (Lowe-McConnell, 1999).

From the moment the length or age of the first maturation is reached, environmental variables begin to influence the individuals so that conditions at spawning time, including its synchrony with food resources available for the larvae and young, are favorable to the survival and development of the brood (McKaye, 1984; Vazzoler, 1996).

The general pattern of higher intensity of gonad maturation for the different species of Cichla at various sites seems indicate the end of the dry season, with spawning occurring from the beginning of the rainy season, when the water level begins to raise (Fontenele, 1950; Lowe-McConnell, 1969;
Machado-Allison, 1990; Novoa et al., 1990; Magalhães et al., 1996; Novoa, 1996; Jepsen et al., 1997; Winemiller et al., 1997; Winemiller \& Jepsen, 1998; Jepsen et al., 1999; Winemiller, 2001). In environments with more uniform hydrological conditions, multiple spawning may occur during the year; nevertheless it is not clear if each individual is capable of several spawnings under natural conditions. Repeated spawning during a single reproductive period constitutes an adaptation to restricted egg and larvae survival conditions (Nikolskii, 1969; Bagenal, 1971; Jepsen et al., 1999). At the Volta Grande Reservoir, spring and summer also brought the best conditions for the reproduction of other fish species (Braga, 2001).

The immature individuals of Cichla matured during the first year of life at a length that varied according to the species and site of occurrence. In Venezuela, Winemiller et al. (1997), Jepsen et al. (1999), and Winemiller (2001) found standard first maturation lengths that varied according to the species: no less than $32.5 \mathrm{~cm}$ for Cichla temensis (Humboldt, 1833); $27 \mathrm{~cm}$ for Cichla orinocensis (Humboldt, 1833); $24.6 \mathrm{~cm}$ for Cichla intermedia (Machado, 1971); $27 \mathrm{~cm}$ for C. ocellaris; and 23 $\mathrm{cm}$ for $C$. cf. monoculus. The species of Cichla at the Volta Grande Reservoir presented similar lengths for the first gonad maturation. Since these lengths are related to growth, they present spatial and temporal variations according to prevailing abiotic and 
biotic environmental conditions in the occupied region or during the period in which the population was subjected to these conditions (Vazzoler, 1996).

Both species of Cichla in the study region had several batches of developing oocytes in their ovaries during the same reproductive period. Thus, these species showed partitioned spawning. The mean fecundities demonstrated that $C$. monoculus was more prolific than was $C$. cf. ocellaris, and fecundity values for both species were related to the length and weight of these fish. Braga \& Gennari Filho (1991) reported that the presence of several modal groups, evidenced by frequency distribution of the oocyte diameters of disassociated ovaries indicated spawning of successive oocyte batches in a single reproductive season, although at different periods. The size of mature oocytes for both species corresponds to values reported by Vazzoler (1996) for a nonmigratory species with external fecundation and displaying parental care.

Multiple or partitioned spawning is characterized by the synchronic development of each oocyte batch and as the more developed batches reach complete maturation they are eliminated (Vazzoler, 1996). Since fish of the genus Cichla present partitioned spawning, their ovaries have oocytes of different dimensions, shapes, and colorations that indicate specific developmental stages (Fontenele, 1950; Magalhães et al., 1996). Jepsen et al. (1999), however, has hypothesized that the energy expendidure for reproduction and brood defense would probably result in single annual spawnings for most individuals.

Fecundity, a particular adaptation to variable conditions, especially mortality, varies mainly in response to food supply and is one of the basic means to adjust the reproduction rate in accordance with environmental condition fluctuation.

Nutrition not only affects fecundity but also the quality of what it generates (Nikolskii, 1969). According to Lowe-McConnell (1999), in fish that live under conditions of very little food supply variation (seasonally and from year to year), energy investment is more efficiently directed to greater efficiency in resource use. Such species tend to exhibit longer life cycles, retarded maturity, frequent and small spawning, often with parental brood care, territoriality, social behavior, and symbiosis with other species.

TABLE 1

Total length $(T L)$, total weight $(T W)$, total number of oocytes $\left(N^{\prime}\right)$, number of developing and mature oocytes $(N)$, fecundity in relation to length $(F R L)$, and fecundity in relation to weight $(F R W)$ of the individuals of Cichla cf. ocellaris from which the ovaries were analyzed.

\begin{tabular}{|c|c|c|c|c|c|}
\hline $\boldsymbol{T L}(\mathbf{m m})$ & $\boldsymbol{T W}(\mathbf{g})$ & $\boldsymbol{N}$ & $\boldsymbol{N}$ & $\boldsymbol{F R L}$ & $\boldsymbol{F R} \boldsymbol{W}$ \\
\hline 347 & 680 & 48600 & 9720 & 28.01 & 14.29 \\
\hline 352 & 811 & 48800 & 12200 & 34.65 & 15.04 \\
\hline 368 & 770 & 71500 & 12155 & 33.02 & 15.78 \\
\hline 379 & 850 & 21500 & 3655 & 9.64 & 4.3 \\
\hline 383 & 1030 & 158200 & 20566 & 53.69 & 19.96 \\
\hline 390 & 1088 & 73000 & 5840 & 14.97 & 5.36 \\
\hline 390 & 1101 & 122000 & 12200 & 31.28 & 11.08 \\
\hline 392 & 1105 & 91900 & 15623 & 39.85 & 14.13 \\
\hline 392 & 1002 & 75100 & 8261 & 21.07 & 8.24 \\
\hline 392 & 1106 & 93200 & 15844 & 40.41 & 14.32 \\
\hline 398 & 1045 & 70900 & 16307 & 40.97 & 15.60 \\
\hline 400 & 1150 & 125900 & 15108 & 37.77 & 13.13 \\
\hline 401 & 1053 & 34500 & & & \\
\hline 406 & 1245 & 120800 & 9664 & 23.8 & 7.76 \\
\hline 410 & 1124 & 57600 & 5760 & 14.04 & 5.12 \\
\hline 416 & 1102 & 46100 & 17979 & 43.21 & 16.31 \\
\hline 476 & 2200 & 122300 & 28129 & 59.09 & 12.78 \\
\hline 492 & 2250 & 142100 & 21315 & 43.32 & 9.47 \\
\hline 537 & 2800 & 116800 & 17520 & 32.62 & 6.25 \\
\hline
\end{tabular}



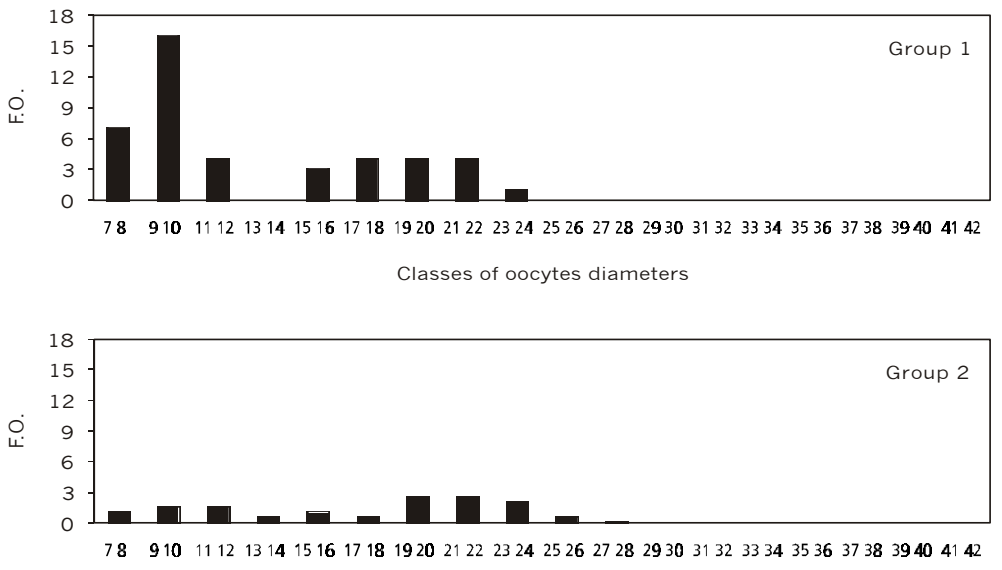

Classes of oocytes diameters
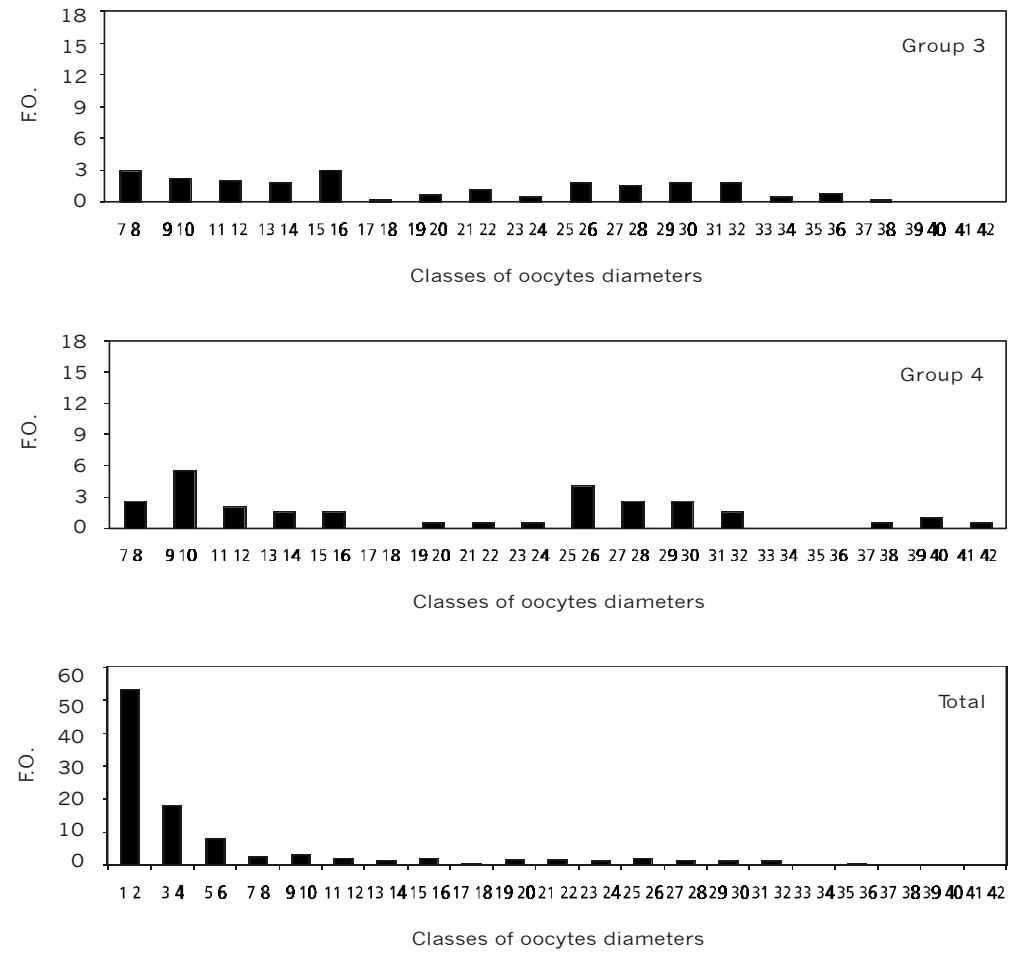

Fig. 6 - Frequency (in percentage) of the diametrical classes of oocytes in d.o.m. (division of ocular micrometer), equivalent to 61.2 micrometers, of Cichla cf. ocellaris divided into groups.

Tropical fresh waters include numerous fish species that present multiple spawning, so there must be an evolutionary advantage in producing several oocyte batches. This might be relate to the dangers inherent in water levels fluctuations to which the first batch is exposed, which is complicated by the fact that many of these fish move only locally to spawn. The many tropical fish species that guard their eggs and young tend to have smaller clutch sizes than species that leave their eggs unprotected. Fecundity also shows an adaptative variation reflecting life conditions within the population, among populations, and among species. 

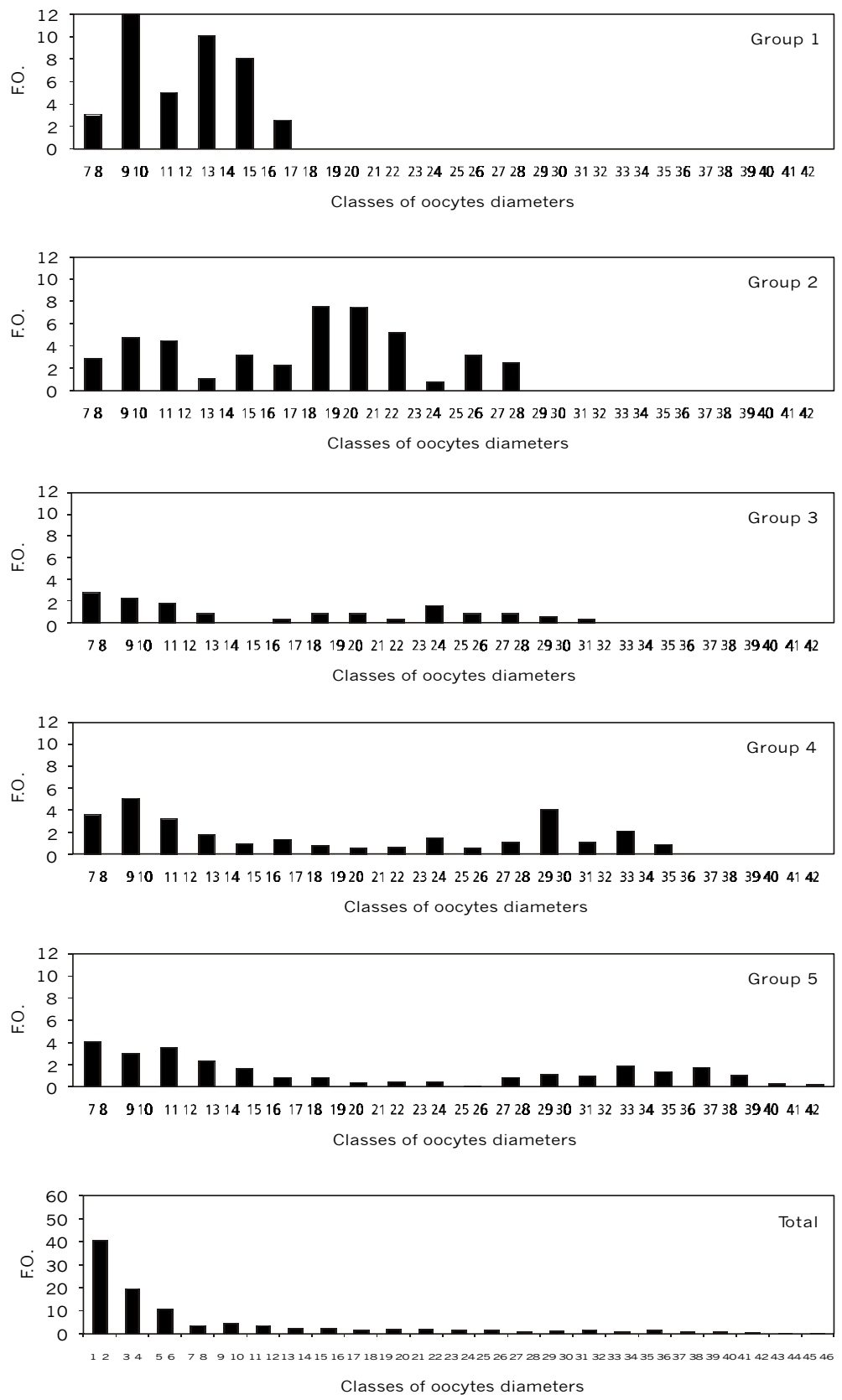

Fig. 7 - Frequency (in percentage) of the diametrical classes of oocytes in d.o.m. (division of ocular micrometer), equivalent to 61.2 micrometers, of Cichla monoculus divided into groups.

In addition, it increases with fish growth, and the point of decline in older fish is a characteristic specific to the population and the species (Nikolskii, 1969). Fecundity generally increases proportionally to fish weight, or its cubic length, so the bigger the female, the higher number of oocytes produced (Galvani \& Coleman, 1998; Lowe-McConnell, 1999). 
TABLE 2

Total length $(T L)$, total weight $(T W)$, total number of oocytes $\left(N^{\prime}\right)$, number of developing and mature oocytes $(N)$, fecundity in relation to length $(F R L)$, and fecundity in relation to weight $(F R W)$ of the individuals of Cichla monoculus from which the ovaries were analyzed.

\begin{tabular}{|c|c|c|c|c|c|}
\hline$T L(\mathrm{~mm})$ & $T W(\mathrm{~g})$ & $N^{\prime}$ & $N$ & $F R L$ & $F R W$ \\
\hline 261 & 531 & 38600 & 18914 & 72.46 & 35.61 \\
\hline 310 & 414 & 19100 & 15089 & 48.67 & 36.44 \\
\hline 326 & 481 & 88300 & 17660 & 54.17 & 36.71 \\
\hline 331 & 497 & 28900 & 19363 & 58.49 & 38.95 \\
\hline 342 & 494 & 102000 & 15300 & 44.73 & 30.97 \\
\hline 350 & 605 & 33700 & 26623 & 76.06 & 44 \\
\hline 358 & 671 & 117800 & 29450 & 82.26 & 43.88 \\
\hline 360 & 758 & 181000 & 10860 & 30.16 & 14.32 \\
\hline 368 & 745 & 41300 & 12803 & 34.79 & 17.18 \\
\hline 372 & 785 & 140400 & 30888 & 83.03 & 39.34 \\
\hline 380 & 843 & 107900 & 32370 & 85.18 & 38.39 \\
\hline 380 & 766 & 93100 & 12103 & 31.85 & 15.8 \\
\hline 382 & 735 & 104800 & 25152 & 65.84 & 34.22 \\
\hline 386 & 634 & 78600 & 15720 & 40.72 & 24.79 \\
\hline 386 & 711 & 109400 & 26256 & 68.02 & 36.92 \\
\hline 386 & 863 & 72500 & 12325 & 31.93 & 14.28 \\
\hline 396 & 1044 & 42300 & 10998 & 27.77 & 10.53 \\
\hline 396 & 830 & 89100 & 8019 & 20.25 & 9.66 \\
\hline 398 & 1070 & 88000 & 11440 & 28.74 & 10.69 \\
\hline 401 & 877 & 49500 & 6930 & 17.28 & 7.9 \\
\hline 404 & 792 & 132800 & 30544 & 75.6 & 38.56 \\
\hline 406 & 1044 & 78500 & 9420 & 23.2 & 9.02 \\
\hline 416 & 1166 & 100200 & 16032 & 38.53 & 13.74 \\
\hline 416 & 1112 & 112000 & 21280 & 51.15 & 19.13 \\
\hline 417 & 1134 & 135500 & 8130 & 19.49 & 7.16 \\
\hline 451 & 1305 & 175600 & 19316 & 42.82 & 14.8 \\
\hline 459 & 1572 & 109300 & 27325 & 59.53 & 17.38 \\
\hline 477 & 1680 & 94800 & 30336 & 63.59 & 18.05 \\
\hline
\end{tabular}


The mean number of mature oocytes for $C$. cf. ocellaris, as well as for $C$. monoculus, was higher than 12,000 , a value very similar to that presented by $C$. ocellaris (Sawaya \& Maranhão, 1946; Novoa et al., 1990; Novoa, 1996; Lowe-McConnell, 1999) and C. temensis (Fontenele, 1950). Nevertheless, it differed from those of $C$. temensis, $C$. intermedia, C. orinocensis (Winemiller, 2001), and C. ocellaris (Fontenele, 1950). These differences are probably due to low sampling or to reduced specimen size.

A few days before spawning, peacock-bass males show nuchal humps and both male and female individuals present red irises and bright body colors. The nuchal hump that some male ciclids develop during the reproductive season might aid in sex recognition (Barlow, 1998) or function as a lipid storage site (Fontenele, 1948); the bright colors might be aposematic for egg and larvae defense or for mutual recognition between a couple (Schroder \& Zaret, 1979).

The males delimitate a territory from which they banish any other male, then the couples form and perform all reproductive behaviors. Peacock-basses are egg, embryo, and larva "keepers" and generally display elaborate behaviors and territoriality (Vazzoler, 1996). The couple seeks a resistant structure like a rock, submersed tree trunk, or any other sort of compact substrate to deposit their eggs (Fontenele, 1950; Lowe-McConnell, 1999; Winemiller, 2001), and the male is more active within the cleaning process (Fontenele, 1950). In many cases, several species might aggregate for nest building at lakeshore sites (Winemiller et al., 1997). In addition to the structure for depositing the eggs, peacock-basses dig their nests in the substrate with their nose; the nests, numbering from two to four, might be circular or oval, depending on the substrate (Fontenele, 1950; Braga, 1952). The eggs are adherent and are laid in the chosen resistant structure; after eclosion, the couple transfers the larvae to one of the previously dug accessory nests (Fontenele, 1950). The larvae have four pairs of adhesive organs on their heads that secrete the mucus which facilitates their adherence to the nest bottom (Fontenele, 1952). The kind and site of the spawning represent an adaptation against predators and favoring food supply for the young (Nikolskii, 1969). In addition, the large number of nests built serves to confuse predators, since only one nest is used to deposit the larvae (Braga, 1952). The reason why these ciclids reproduce in lentic waters is the zooplankton supply available for the larvae; this food source is generally more abundant in lakes (Zaret, 1980).
After a few days, the larvae become free swimmers and the couple accompanies the school. Chemical (pheromones) as well as visual signals may be involved in keeping the young next to their parents. Predator pressure seems to be an important factor in the evolution of some forms of parental care of eggs and the young, e.g., participation of both parents in guarding the young after they become free swimmers is very important (Lowe-McConnell, 1999). Generally, in ciclids displaying brood care by both parents, the males are larger than the females and a division of labor exists: females guard the eggs and larvae while males patrol and repel any possible predators (Barlow, 1974). The benefits of bi-parental brood care include collaboration in the division of labor necessary to repel predators and presence of the remaining parent when the other dies or abandons the brood (Annett et al., 1999). All of the aspects of Cichla species reproduction show relationships between the way of life, habitat, and strategies. The low fecundity, partitioned spawning, bi-parental brood care, and food supply for larvae and young in lentic environments are intimately associated within the complex reproductive behavior of these fish.

Acknowledgements - The authors wish to thank Electric Energy Company of Minas Gerais (CEMIG) and CAPES for financial support

\section{REFERENCES}

AGOSTINHO, A. A., 1994, Pesquisas, monitoramento e manejo da fauna aquática em empreendimentos hidrelétricos. In: Seminários sobre fauna aquática e o setor elétrico brasileiro, 1: 38-61.

AGOSTINHO, A. A. \& JULIO JR., H. F., 1996, Peixes de outras águas. Ciência Hoje, 21: 36-44.

ANNETT, C. A., PIEROTTI, R. \& BAYLIS, J. R., 1999, Male and female parental roles in the monogamous cichlid, Tilapia mariae, introduced in Florida. Env. Biol. Fishes, 54: 283-293.

BAGENAL, T. B., 1971, The interrelation of the size of fish eggs, the date of spawning and the production cycle. J. Fish Biol., 3: 207-219.

BARLOW, G. W., 1974, Contrasts in social behavior between Central American cichlid fishes and coral-reef surgeon fishes. Amer. Zoolog., 14: 9-34.

BARLOW, G. W., 1998, Sexual-selection models for exaggerated traits are useful but constraining. Amer. Zoolog., 38: 59-69.

BEDARF, A. T., MCKAYE, K. R., VAN DEN BERGHE, E., PEREZ, L. J. L. \& SECOR, D. H., 2001, Initial six-year expansion of an introduced piscivorous fish in a tropical Central American lake. Biological Invasions, 3: 391-404.

BLUMER, L. S., 1979, Male parental care in the bony fishes. The Quarterly Review of Biology, 54: 149-161.

BLUMER, L. S., 1986, The function of parental care in the brown bullhead Ictalurus nebulosus. American Midland Naturalist, 115: 234-238. 
BRAGA, F. M. S., 2001, Reprodução de peixes (Osteichthyes) em afluentes do reservatório de Volta Grande, Sudeste do Brasil. Iheringia, 91: 67-74.

BRAGA, F. M. S. \& GENNARI FILHO, O., 1991, Estudos sobre a fecundidade, desova e mortalidade natural de Moenkhausia intermedia (Characidae, Tetragonopterinae) na represa de Barra Bonita, rio Piracicaba, SP. Naturalia, 16: $55-68$.

BRAGA, F. M. S. \& GOMIERO, L. M., 1997, Análise da pesca experimental realizada no reservatório de Volta Grande, rio Grande (MG/SP). Boletim do Instituto de Pesca, 24: 131-138.

BRAGA, R., 1952, Ninhos de tucunarés Cichla temensis Humboldt e Cichla ocellaris Bloch \& Schneider. Rev. Brasil. Biol., 12: 273-278.

ELVIRA, B. \& ALMODÓVAR, A., 2001, Freshwater fish introductions in Spain: facts and figures at the beginning of the 21st century. J. Fish Biol., 59(Suppl. A): 323-331.

FONTENELE, O., 1948, Um caráter sexual secundário extragenital nos tucunarés (Actinopterygii, Cichlidae). Rev. Brasil. Biol., 8: 185-188.

FONTENELE, O., 1950, Contribuição para o conhecimento da biologia dos tucunarés (Actinopterygii, Cichlidae), em cativeiro. Aparelho de reprodução. Hábitos de desova e incubação. Rev. Brasil. Biol., 10: 503-519.

FONTENELE, O., 1952, Notas sobre os órgãos adesivos dos tucunarés (Actinopterygii, Cichlidae). Rev. Brasil. Biol., 12: 363-368.

GALVANI, A. P. \& COLEMAN, R. M., 1998, Do parental convict cichlids of different sizes value the same brood number equally? Animal Behaviour, 56: 541-546.

GITTLEMAN, J. L., 1981, The phylogeny of parental care in fishes. Animal Behaviour, 29: 936-941.

GODFRAY, H. C. J., 1995, Evolutionary theory of parentoffspring conflict. Nature, 376: 133-138.

GOODWIN, N. B., BALSHINE-EARN, S. \& REYNOLDS, J. D., 1998, Evolutionary transitions in parental care in cichlid fish. Proceed. Royal Society London B, 265: 2265-2272.

JEPSEN, D. B., WINEMILLER, K. O. \& TAPHORN, D. C., 1997, Temporal patterns of resource partitioning among Cichla species in a Venezuelan blackwater river. J. Fish Biol., 51: 1085-1108.

JEPSEN, D. B., WINEMILLER, K. O., TAPHORN, D. C. \& RODRIGUEZ OLARTE, D., 1999, Age structure and growth of peacock cichlids from rivers and reservoirs of Venezuela. J. Fish Biol., 55: 433-450.

LOWE-McCONNELL, R. H., 1969, The cichlid fishes of Guyana, South America, with notes on their ecology and breeding behaviour. Zoological Journal of the Linnean Society, 48: 255-302.

LOWE-McCONNELL, R. H., 1999, Estudos ecológicos de comunidades de peixes tropicais. Translation of A. E. A. M. Vazzoler, A. A. Agostinho \& P. Cunnighan, São Paulo. Ed. da Universidade de São Paulo. Original title: Ecological studies in tropical fish communities, 535p.

MACHADO-ALLISON, A., 1990, Ecología de los peces de las areas inundables de los llanos de Venezuela. Interciencia, 15: 411-423.
MAGALHÃES, A. L. B., SATO, Y., RIZZO, E., FERREIRA, R. M. A. \& BAZZOLI, N., 1996, Ciclo reprodutivo do tucunaré Cichla ocellaris (Schneider, 1801) na represa de Três Marias, MG. Arquivos Brasileiros de Medicina Veterinária e Zootecnia, 48(Suppl.1): 85-92.

McKAYE, K. R., 1977, Competition for breeding sites between the cichlid fishes of lake Jiloá, Nicaragua. Ecology, 58: 291-302.

McKAYE, K. R., 1984, Behavioral aspects of cichlid reproductive strategies: patterns of territoriality and brood defense in Central American substratum spawners and African mouth brooders. In: G. W. Potts \& R. J. Wotton (eds.), Fish reproduction: strategies and tactics. Academic Press, London, pp. 245273.

MURRAY, A. M., 2001, The fossil record and biogeography of the Cichlidae (Actinopterygii: Labroidei). Biological Journal of the Linnean Society, 74: 517-532.

NIKOLSKII, G. V., 1969, Theory of fish population dynamics. Oliver \& Boyd, Edinburgh, 321p.

NOVOA, D. F. R., KOONCE, J., LOCCI, A. \& RAMOS, F., 1990, La ictiofauna del lago de Guri: composición, abundancia y potencial pesquero. II. Evaluación del potencial pesquero del lago de Guri y estrategias de ordenamiento pesquero. Memoria, 49: 159-197.

NOVOA, D. F. R., 1996, Aspectos generales sobre la biología, pesquería, manejo y cultivo del pavón (Cichla orinocensis y Cichla temensis) en el lago de Guri y otras areas de la región Guayana. Natura Caracas, 96: 34-39.

SAWAYA, P. \& MARANHÃO, A. A., 1946, A construção de ninhos e a reprodução de alguns peixes neotrópicos (Cichlidae - gen. Cichla e Astronotus). Boletim da Faculdade de Filosofia e Ciências da Universidade de São Paulo, 11: 357-381.

SCHRODER, S. L. \& ZARET, T. M., 1979, The adaptative significance of color patterns in Cichla ocellaris. Copeia, 1: $43-47$.

VAZZOLER, A. E. A. M., 1996, Biologia da reprodução de peixes teleósteos: teoria e prática. Nupelia, Maringá-PR, $169 \mathrm{p}$.

WILLIAMS, J. D., WINEMILLER, K. O., TAPHORN, D. C. \& BALBAS, L., 1998, Ecology and status of piscivores in Guri, an oligotrophic tropical reservoir. North American Journal of Fisheries Management, 18: 274-285.

WINEMILLER, K. O., 1989, Patterns of variation in life history among South American fishes in seasonal environments. Oecologia, 81: 225-241.

WINEMILLER, K. O., 2001, Ecology of peacock cichlids (Cichla spp.) in Venezuela. Journal of Aquariculture and Aquatic Sciences, 9: 93-112.

WINEMILLER, K. O. \& JEPSEN, D. B., 1998, Effects of seasonality and fish movement on tropical river food webs. J. Fish Biol., 53(Suppl. A): 267-296.

WINEMILLER, K. O., TAPHORN, D. C. \& BARBARINO, A., 1997, The ecology of Cichla (Cichlidae) in two blackwater rivers of southern Venezuela. Copeia, 4: 690696.

ZARET, T. M., 1980, Life history and growth relationships of Cichla ocellaris, a predatory South American cichlid. Biotropica, 12: 144-157.

ZARET, T. M., 1982, The stability/diversity controversy: a test of hypotheses. Ecology, 63: 721-731. 